\title{
Bimodal Distribution of Erythrocytes in Heterozygote for Strong Mediterranean Glucose-6-phosphate Dehydrogenase Deficiency*
}

\author{
E. SARTORI, F. PANIZON, and F. ZACCHELLO \\ From the Padiatric Clinic, University of Pavia, Pavia, Italy
}

Haemolytic favism is a condition that affects children predominantly, and is frequent in Sardinia and in other Mediterranean areas. It is related to a deficiency of the enzyme glucose-6-phosphate dehydrogenase (G6PD) in the erythrocytes, as is 'primaquine sensitivity' of American Negroes (Larizza, Brunetti, Grignani, and Ventura, 1958; Siniscalco, Motulsky, Latte, and Bernini, 1960; Carson, Flanagan, Ickes, and Alving, 1956; Gross, Hurwitz, and Marks, I958; Tarlov, Brewer, Carson, and Alving, 1962). In both conditions the deficiency is due to a mutant allele of an X-linked gene, but in haemolytic favism the enzyme is of an electrophoretically slow (B) type, while in primaquine sensitivity it is of a fast (A) type. The deficiency is definitely more pronounced in haemolytic favism, but recently a mild deficiency of the B type has been found in Greece (Kirkman, 1962; Kirkman, Schettini, and Pickard, 1964; Porter, Boyer, Watson-Williams, Adam, Szeinberg, and Siniscalco, 1964; Stamatoyannopoulos, Panayotopoulos, and Papayannopoulou, 1964).

In spite of the different dose of X-linked alleles, hemizygous males and homozygous females, both normal and mutant, do not differ in their mean G6PD enzyme levels (Adinolfi, Bernini, Carcassi, Latte, Motulsky, and Siniscalco, r960; Davidson, Childs, and Siniscalco, 1964) nor are there dosage differences among individuals with abnormal numbers of sex chromosomes, such as $\mathrm{XO}, \mathrm{XXY}$, XXX, XXXY, XXXX (Grumbach, Marks, and Morishima, r962; Harris, Hopkinson, Spencer, Court Brown, and Mantle, 1963).

In both the American and Mediterranean

Received May 20, 1965

* This research has been supported in part by C.N.R. deficiencies, heterozygous females present enzyrite levels that are intermediate between but also overlap with those of normal and of mutant hemizygouss males (Beutler, Yeh, and Fairbanks, I962; Adinol Davidson, Latte, Meera Khan, Piomelli, Rataz $\overline{\text {, }}$ and Siniscalco, 1963; Davidson et al., 1964). Moreover, Sardinian females clinically affect with haemolytic favism are observed with a frequency that is higher than the number of homgzygotes and lower than the number of heterozygotes expected on the basis of the local gene frequenciss (E. Sartori, unpublished data).

These discrepancies could be explained by the Lyon hypothesis (1962) which postulates that one of the two $\mathrm{X}$ chromosomes of normal females genetically inactive and that either of the two $\mathrm{X}$ chromosomes may be inactivated in earify embryonic life at random in different cells of the same individual.

According to Beutler et al. (1962) an implication of the hypothesis is the existence, in the G6PD deficiegst heterozygotes, of two distinct cell populations, one normal and one deficient. This assumption has been submitted to experimental tests by many authors. Among those who confirm the hypothesis, some hate not considered sufficiently the possibility that the erythrocytes can behave as if they were composed iof two distinct populations also in hemizygous males, provided that their behaviour is referred to an apprif priate single measurement. Thus it was well known thipt in primaquine-sensitivity the haemolysis was clinicafly and haematologically self-limited and that the linkt was related to cell age as well as to the dose of the difg (Dern, Beutler, and Alving, 1954; Kellermeyer, Tarlof, Schrier, Carson, and Alving, 196I). The haemolysis is self-limited also in haemolytic favism (Sartori and Panizon, 1957). Furthermore Frischer, Bowman, aAd Carson (1964) and Papayannopoulou and Stamatoyanopoulos (1964), applying the cyanmethaemoglobin 
elution technique to the methaemoglobin reduction test of Brewer, Tarlov, and Alving (1960), were able to visualize microscopically two kinds of erythrocytes in mild G6PD-deficient males as well as in intermediate females, as found by Sansone, Rasore-Quartino, and Veneziano (1963) and by Tönz and Rossi (1964).

These objections do not apply to the experiments of Beutler et al. (1962) who reported that the disappearance of reduced glutathione from the erythrocytes of females with intermediate red-cell G6PD activity challenged with acetylphenylhydrazine and the reduction of their methaemoglobin occurred at two different rates, as in artificial mixtures of enzyme-deficient and normal erythrocytes. In our hands the methaemoglobin reduction as used by these authors failed to give consistent results. More recently, Beutler and Baluda (I964), using blood of two Negro females with intermediate red-cell G6PD-activity and with the sickle-cell trait, succeeded by means of sickling and successive millipore filtering in separating the erythrocytes in which methaemoglobin was still present from those in which it had been reduced. They found that the filtered not sickled methaemoglobin-rich erythrocytes were present in relevant amount and had a very little G6PD-activity. Using another approach, Davidson, Nitowsky, and Childs (1963) had previously demonstrated two kinds of cells by cloning skin biopsies of Sardinian women heterozygous for quantitative enzyme deficiency and of American Negro women heterozygous for qualitative electrophoretic enzyme variants.

Evidence against the hypothesis derives in the first place from failure to detect in the blood of heterozygotes a portion of $\mathrm{DF}^{\mathbf{3 2}} \mathrm{P}$-labelled erythrocytes behaving in vivo as normal ones (Brewer, Tarlov, and Powell, I962), and secondly for failure to separate from the blood of double heterozygotes $\mathrm{Xg}(\mathrm{a}+)$ and $\mathrm{Xg}(\mathrm{a}-)$ erythrocytes with different G6PD activities, which could easily be separated from artificial mixtures of hemizygous bloods (Gorman, Dire, Treacy, and Cahan, 1963).

As to this negative evidence, we think that the longterm survival behaviour in vivo of a double population of erythrocytes can hardly be predicted with sufficient precision. Furthermore, the $\mathrm{Xg}^{\text {a }}$ locus may belong to a non-inactivated region of the $\mathrm{X}$ chromosome. Such an hypothesis has been formulated by Russell (I963) to explain some variegated type position effects in the mouse, by limitation in spread and in region of origin of the inactivation of the mammalian $\mathrm{X}$ chromosome.

In conclusion, the existence of a true erythrocyte mosaic in females heterozygous for G6PD-deficiency is still open to some doubt, and further investigations are desirable.

Given the appropriate variable, two normal distributions of it found in heterozygotes would prove the mosaic, while a single distribution would exclude it. We searched accordingly for a variable that would give normal distributions for both normal and mutant hemizygous erythrocytes and first tried with primaquine. Panizon and
Zacchello (I965) in fact observed that erythrocytes of enzyme-deficient males, labelled with ${ }^{51} \mathrm{Cr}$ and then transfused, underwent an almost complete destruction within one day when first incubated with $0.10 \mathrm{mg} . / \mathrm{ml}$. primaquine, while only about half the deficient cells were destroyed if the drug was lowered to $0.02 \mathrm{mg} . / \mathrm{ml}$. Primaquine, however, proved to be unsuitable, since at higher doses it modifies the blood physically, and it was, therefore, impossible to obtain a distribution for normal cells. We finally succeeded in our purpose by first damaging the erythrocytes in vitro with increasing concentrations of menadione sodium bisulphite, the hydrosoluble vitamin $\mathrm{K}_{3}$, and then destroying the damaged ones in vivo by means of transfusing the blood into compatible recipients, after having labelled it with ${ }^{51} \mathrm{Cr}$. The proportion of destroyed cells was finally inferred from short-term survival determinations.

\section{Material and Methods}

Subjects. Blood was drawn from 8 healthy Italian adults, Wassermann negative and without history of malaria. Four were males, two of them normal and two strongly deficient for erythrocyte G6PD-activity. The other four were females heterozygous for the mutant gene. In three, heterozygosity was proven because each had at least one normal and one enzyme-deficient son; in the fourth, heterozygosity was strongly presumptive because her father had suffered from haemolytic favism, but she presented only minor fava-induced disorders and repeatedly showed intermediate values for erythrocyte G6PD activity. Recipients were normal volunteers, compatible for $\mathrm{ABO}$ and $\mathrm{Rh}$ blood groups.

Glutathione and Enzyme Determinations. Erythrocyte-reduced glutathione (GSH), before and after incubation (for 2 hours at $37^{\circ} \mathrm{C}$. with $5 \mathrm{mg}$. $/ \mathrm{ml}$. acetylphenylhydrazine and $2 \mathrm{mg}$. $/ \mathrm{ml}$. glucose), was determined by the method of Beutler, Duron, and Kelly (1963). Studies were carried out in the Bausch and Lomb spectrophotometer and expressed as $\mathrm{mg}$./100 $\mathrm{ml}$. packed erythrocytes.

Erythrocyte G6PD activity was measured with the 'Boehringer Test Combination', using the Beckman DB spectrophotometer with recorder, at a temperature of $18-22^{\circ} \mathrm{C}$. The activity was expressed as optical density units per minute/100 g. Hb. Erythrocyte acid phosphomonoesterase (APM) was determined by the method of Oski, Shahidi, and Diamond (1963) and expressed as mg. phenol in 30 minutes per $100 \mathrm{~g}$. $\mathrm{Hb}$. Erythrocyte catalase activity was tested by the perborate method of Feinstein as used by Tarlov and Kellermeyer (I96I) and expressed as mEq of $\mathrm{NaBO}_{3}$ decomposed during the first minute.

The results of all these determinations in the blood of the eight donors are listed in Table I. 
TABLE I

GLUTATHIONE AND ENZYME DETERMINATIONS IN 2 NORMAL, 2 G6PD-DEFICIENT, AND 4 HETEROZYGOUS FEMALES

\begin{tabular}{|c|c|c|c|c|c|}
\hline $\begin{array}{l}\text { Subject No., Sex, } \\
\text { and Age (yr.) }\end{array}$ & GSH & G6PD & APM & Catalase & MSB* \\
\hline $\begin{array}{lll}1 & M & 25 \dagger \\
2 & M & 26 \dagger \\
3 & M & 55 \ddagger \\
4 & M & 42 \ddagger \\
5 & F & 51 \S \\
6 & F & 28 \S \\
7 & F & 32 \S \\
8 & F & 21 \S\end{array}$ & $\begin{array}{l}6 I \text { and } 58 \\
86 \text { and } 80 \\
35 \text { and } 16 \\
4 I \text { and } 8 \\
66 \text { and } 51 \\
51 \text { and } 26 \\
47 \text { and } 42 \\
81 \text { and } 64\end{array}$ & $\begin{array}{r}1130 \\
1070 \\
0 \\
0 \\
710 \\
590 \\
720 \\
650\end{array}$ & $\begin{array}{l}975 \\
822 \\
818 \\
967 \\
693 \\
822 \\
891 \\
831\end{array}$ & $\begin{array}{l}0.24 \\
0.26 \\
0.16 \\
0.13 \\
0.24 \\
0.23 \\
0.24 \\
0.26\end{array}$ & $\begin{array}{r}85 \cdot 7 \\
85 \cdot 3 \\
5 \cdot 0 \\
3 \cdot 7 \\
51 \cdot 1 \\
24 \cdot 6 \\
57 \cdot 0 \\
52 \cdot 8\end{array}$ \\
\hline
\end{tabular}

* 24-hour residual percentage of ${ }^{51} \mathrm{Cr}$-labelled erythrocytes transfused after incubation with $\mathrm{I} \times 10^{-4} \mathrm{M}$ menadione sodium bisulphite.

$\dagger$ Normal.

¥ G6PD deficient.

§ Heterozygous.

Incubation and Labelling. Standards having been derived from preliminary experiments, $32 \mathrm{mg}$. menadione sodium bisulphite (MSB) were dissolved each time in $10 \mathrm{ml}$. phosphate-buffered saline at $\mathrm{pH} 7.40$ and sterilized by means of boiling. This solution was brought from 320 down to $\mathrm{I} \cdot 25 \mathrm{mg}$./100 ml. by serial twofold dilutions. To $5 \mathrm{ml}$. blood was added $\mathrm{I} \mathrm{ml}$. solution and the following range of final concentrations, expressed in Moles $\times 10^{-4}$, was obtained: $\frac{1}{16} ; \frac{1}{8} ; \frac{1}{4} ; \frac{1}{2} ; 1 ; 2 ; 4 ; 8 ; 16$. From each donor, 7 samples of heparinized blood, fresh or stored for no longer than 12 hours at about $4^{\circ} \mathrm{C}$., to which were added $\mathrm{I} \%$ of a sterile $20 \%$ glucose solution, were tried against consecutive dilutions of MSB, ranging

TABLE II

STUDIES WITH RADIOACTIVE ${ }^{51} \mathrm{CR}^{*}$

\begin{tabular}{|c|c|c|c|c|c|c|c|c|}
\hline \multirow{2}{*}{ MSB ro $^{-4} M$} & \multicolumn{8}{|c|}{ Subject } \\
\hline & I & 2 & 3 & 4 & 5 & 6 & 7 & 8 \\
\hline$\frac{1}{16}$ & - & - & $90 \cdot 0$ & $91 \cdot 3$ & - & - & - & 一 \\
\hline$\frac{1}{8}$ & - & - & $\begin{array}{l}87.0 \\
48.5\end{array}$ & $\begin{array}{l}80.8 \\
26.6\end{array}$ & $\begin{array}{r}90 \cdot 7 \\
0.2\end{array}$ & $\begin{array}{l}87.8 \\
34.5\end{array}$ & $\begin{array}{r}88.6 \\
5.0\end{array}$ & $\begin{array}{r}92 \cdot 2 \\
6 \cdot 1\end{array}$ \\
\hline 1 & $\begin{array}{r}89.4 \\
-0.4\end{array}$ & $\begin{array}{r}92 \cdot 3 \\
5 \cdot 5\end{array}$ & $\begin{array}{l}38 \cdot 5 \\
20 \cdot 5\end{array}$ & $\begin{array}{l}54.2 \\
31.7\end{array}$ & $\begin{array}{l}90 \cdot 5 \\
27 \cdot 3\end{array}$ & $\begin{array}{l}53.3 \\
19.9\end{array}$ & $\begin{array}{l}83.6 \\
17.8\end{array}$ & $\begin{array}{l}86 \cdot 1 \\
26.8\end{array}$ \\
\hline$\frac{1}{2}$ & $\begin{array}{r}89 \cdot 8 \\
4 \cdot 1\end{array}$ & $\begin{array}{r}86.8 \\
1.5\end{array}$ & $\begin{array}{l}18 \cdot 0 \\
13 \cdot 0\end{array}$ & $\begin{array}{l}22.5 \\
18.8\end{array}$ & $\begin{array}{l}63.2 \\
12.1\end{array}$ & $\begin{array}{l}33.4 \\
8.8\end{array}$ & $\begin{array}{r}65.8 \\
8.8\end{array}$ & $\begin{array}{l}59.3 \\
6.5\end{array}$ \\
\hline $\mathbf{I}$ & $\begin{array}{l}85.7 \\
10.2\end{array}$ & $\begin{array}{r}85.3 \\
7.5\end{array}$ & $\begin{array}{r}5.0 \\
4.0\end{array}$ & $\begin{array}{r}3.7 \\
1.1\end{array}$ & $\begin{array}{r}51 \cdot 1 \\
7 \cdot 4\end{array}$ & $\begin{array}{r}24.6 \\
2.5\end{array}$ & $\begin{array}{r}07.0 \\
13 \cdot 2\end{array}$ & $\begin{array}{r}52.8 \\
1.7\end{array}$ \\
\hline 2 & $\begin{array}{l}75.5 \\
32.0\end{array}$ & $\begin{array}{l}77.8 \\
26.5\end{array}$ & $\begin{array}{l}\mathrm{I} .0 \\
1.0\end{array}$ & $\begin{array}{l}2.6 \\
2.5\end{array}$ & $\begin{array}{l}43.7 \\
26.5\end{array}$ & $\begin{array}{r}22 \cdot 1 \\
7 \cdot 4\end{array}$ & $\begin{array}{l}43.8 \\
18.0\end{array}$ & $\begin{array}{r}5 \mathrm{I} \cdot \mathrm{I} \\
2 \cdot 8\end{array}$ \\
\hline 4 & $\begin{array}{l}43 \cdot 5 \\
33.1\end{array}$ & $\begin{array}{l}51 \cdot 3 \\
50.8\end{array}$ & 0.0 & $0 \cdot 1$ & $\begin{array}{l}17 \cdot 2 \\
13 \cdot 0\end{array}$ & $\begin{array}{l}14.7 \\
15.3\end{array}$ & $\begin{array}{l}25.8 \\
20.4\end{array}$ & $\begin{array}{l}48 \cdot 3 \\
37 \cdot 3\end{array}$ \\
\hline 8 & $\begin{array}{l}10.4 \\
10.0\end{array}$ & $\begin{array}{l}0.0 \\
0.5 \\
0.1\end{array}$ & - & 一 & 4.2 & -0.6 & $5 \cdot 4$ & $1 \cdot 0$ \\
\hline 16 & $\begin{array}{l}8 \cdot 0 \\
2 / 4\end{array}$ & $\begin{array}{l}0.1 \\
0.4\end{array}$ & - & - & - & - & - & - \\
\hline
\end{tabular}

The percentage loss of radioactivity for each increase of concentration is shown in italics. The values obtained with the concentration of $\mathrm{I} \times \mathrm{IO}^{-4} \mathrm{M}$, found to be discriminant between the two kinds of cells, are shown in bold.

* See text. from $\frac{1}{16}$ to $4 \times 10^{-4} \mathrm{M}$ for the G6PD-deficient, fro $\frac{1}{8}$ to $8 \times 10^{-4} \mathrm{M}$ for the intermediate, and from $\frac{1}{4}$ to $\mathrm{I} \bar{D}_{\mathrm{D}} \times$ $10^{-4} \mathrm{M}$ for the G6PD-normal donors (see Table II). For all samples the incubation time was 3 hours. At the th hour I $\mu \mathrm{c}{ }^{51} \mathrm{Cr}$ salt $/ \mathrm{kg}$. of the recipient's body weight was added to every specimen, which was then incubatedfor a further 30 minutes. Finally the plasma was remofed by gentle centrifugation and the erythrocytes were suspended in sterile saline and injected intravenously

Recording. For each donor seven recipients were injected, and from these blood was drawn in dupliegte Io minutes and 24 hours after the injection. The radioactivity of the specimen was then measured sinfulltaneously for all those belonging to the same dowor. The mean value after 24 hours was referred to hat after Io minutes as $100 \%$. Preliminary experimbits showed that the mean difference was 3.0 between .The duplicates of the same specimen and 1.9 between the percentage found at 24 hours and that calculated fiom the values obtained at 12 and 36 hours. Preliminary experiments on artificial mixtures of normal and mutant hemizygous bloods, incubated with $0.10 \mathrm{mg}$. $\mathrm{ml}$. of primaquine or with I $\times 1^{-4} \mathrm{M} \mathrm{MSB}$, also sho ed good agreement at the 24-hour survival rate with the expected value based on the proportions of the kinds of cells mixed. It was, therefore, assumed what the radioactive salt entered equally into normal and mutant erythrocytes and was equally eluted from boh, and that the decay of radioactivity during the short time considered was caused chiefly by destruction of erythrocytes altered by the exposure to MSB.

As different quantities of the substance added to the same blood led to different amounts of destromed erythrocytes, it was further assumed that there was a continuous variability in their resistance against MSB damage and that this variability might be reflected the differences between the radioactivity percentage figures of the 24-hour samples obtained after incubation with subsequent MSB dilutions. Since we forind good agreement between the values obtained from The blood of the same donor tested against the same dilutions at different times in different recipients, we also posinlated that the individual differences among the recipients would not introduce any serious bias.

\section{Results}

음

The results listed in Table II and summariQed in Fig. I were essentially as follows: (I) Bothfin the normal and in the mutant hemizygous bleded the resistance of the erythrocytes against MSBdamage behaves as a nearly normally distributed function of the logarithm of the MSB-concentrati

(2) There is a considerable difference between the ranges of concentration that damage the normal and those that damage the mutant erythrocywe the latter being definitely lower.

(3) There is almost no overlapping of the towo 


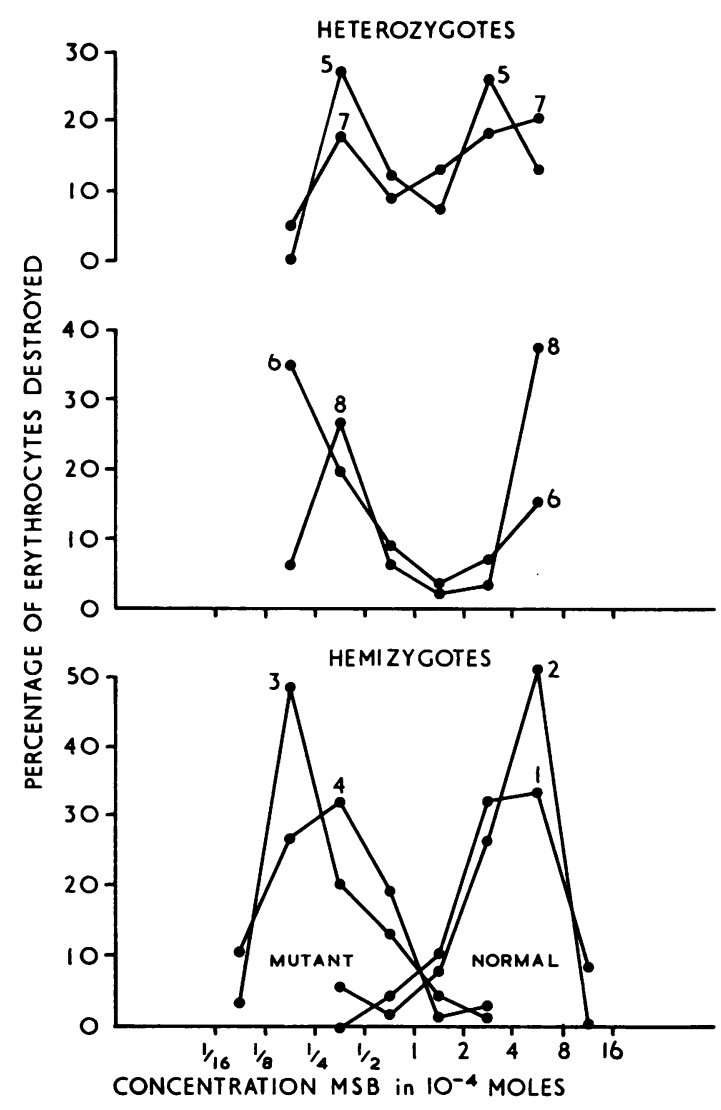

FIG. I. Distribution curves of hemizygotes, normal and mutant, and of heterozygotes for glucose-6-phosphate dehydrogenase deficiency for short-term erythrocyte survival in vivo after incubation with increasing concentrations of menadione sodium bisulphite (MSB) in vitro. On the ordinates the percentage of erythrocytes destroyed, on the abscissa the concentration of MSB in $\mathrm{IO}^{-4}$ Moles. The figures on the curves refer to the subject's number entered in the Tables.

distributions in the range between $\frac{1}{2}$ and $2 \times 10^{-4} \mathrm{M}$, and the concentration of $\mathrm{I} \times \mathrm{IO}^{-4}(\mathrm{MSB} \mathrm{I})$ is discriminant between the two kinds of cells, the strongly deficient erythrocytes being nearly all destroyed and the normal ones on the contrary nearly completely preserved.

(4) Whereas the distributions of the hemizygous males are unimodal, those of the four intermediate G6PD-deficient heterozygous females are bimodal, showing two distinct peaks, one in the range of the normal and the other in that of the mutant hemizygotes.

(5) The ratio observed between the two kinds of erythrocytes in the heterozygotes, as measured by the 24-hour radioactivity-decay at the MSB I, varies little in three but significantly in one female. From the values entered in Table II it can be seen that the proportion of normal erythrocytes ranges from $24 \cdot 6$ to $57 \cdot 0 \%$, with a mean of $46 \cdot 5 \%$.

\section{Discussion}

We feel that our results suggest the existence of two distinct populations of erythrocytes in females heterozygous for strong Mediterranean G6PDdeficiency. One is more damaged by MSB than the other and behaves as the single one of strong G6PD-deficient males. The other on the contrary behaves exactly as the single population of G6PDnormal males.

As shown by Zacchello (1963), incubation with MSB gives rise to the appearance of methaemoglobin and of Heinz-bodies in normal erythrocytes, and, at a higher dosage, equal to that determining complete destruction in vivo, it causes GSHdisappearance and loss of potassium. Furthermore our heterozygote with the lowest G6PD-enzyme level has the highest proportion of erythrocytes damaged by the MSB I (Subject No. 6), lower only than those of the mutant hemizygotes. All this strongly suggests that the two populations also differ in their mean G6PD-activity, as first postulated by Beutler et al. (1962).

Though we have not tested homozygous females to show that they have a single population, we conclude that the results presented here do complete those of Beutler and Baluda (1964) and agree with the hypothesis of Lyon (1962) on the behaviour of $\mathrm{X}$-linked genes.

\section{Summary}

Short-term in vivo survival studies were carried out with erythrocytes damaged in vitro by increasing doses of menadione sodium bisulphite from two normal and two mutant hemizygotes and from four heterozygotes for strong Mediterranean glucose-6phosphate dehydrogenase deficiency.

The rate of the erythrocyte destruction referred to the menadione salt concentration showed a unimodal distribution in the hemizygotes, in ranges considerably higher in the normal than in the mutant ones. In the heterozygotes it showed a bimodal distribution, with two distinct peaks corresponding to the modes of the former.

This is considered proof of the existence of a true erythrocyte mosaic in females heterozygous for the enzyme deficiency, as hypothesized by Lyon. 


\section{REFERENCES}

Adinolfi, M., Bernini, L., Carcassi, U., Latte, B., Motulsky, A. G., and Siniscalco, M. (1960). Indagini genetiche sulla predisposizione al favismo. I. Il problema e i metodi. Fluttuazioni stagionali dei livelli di glucoso-6-fosfato-deidrogenasi in Sardegna. Interazione con la talassemia al livello fisiologico. Accademia Lincei, Rend. Sc. Fis. Mat. e Nat., 28, 716.

, Davidson, R. G., Latte, B., Meera Khan, P., Piomelli, S., Ratazzi, M., and Siniscalco, M. (1963). Ulteriori dati sulla genetica formale e di popolazione dell'enzimopenia G6PD (glucoso-6-fosfato-deidrogenasi). Atti A.G.I., VIII, 96.

Beutler, E., and Baluda, M. C. (1964). The separation of glucose6-phosphate-dehydrogenase-deficient erythrocytes from the blood of heterozygotes for glucose-6-phosphate-dehydrogenase defciency. Lancet, $1,189$.

-, Duron, O., and Kelly, B. M. (1963). Improved method for the determination of blood glutathione. F. Lab. clin. Med., 61, 882 -, Yeh, M., and Fairbanks, V. F. (1962). The normal human female as a mosaic of X-chromosome activity; studies using the gene for G-6-PD-deficiency as a marker. Proc. nat. Acad. Sci. (Wash.), 48, 9.

Brewer, G. J., Tarlov, A. R., and Alving, A. S. (I960). Methaemoglobin reduction test. A new, simple, in vitro test for identifying primaquine-sensitivity. Bull. Wld Hlth Org., 22, 633.

$\longrightarrow$, and Powell, R. D. (1962). Genetic implications of diisopropyl fluorophosphate (DFP) ${ }^{32}$-erythrocyte survival studies in negro females heterozygous for glucose-6-phosphate dehydrogenase deficiency. $\mathcal{f}$. clin. Invest., 41, 1348.

Carson, P. E., Flanagan, C. L., Ickes, C. E., and Alving, A. S. (1956). Enzymatic deficiency in primaquine-sensitive erythrocytes. Science, 124, 484 .

Davidson, R. G., Childs, B., and Siniscalco, M. (1964). Genetic variations in the quantitative control of erythrocyte glucose-6phosphate-dehydrogenase activity. Ann. hum. Genet., 28, 61.

-, Nitowsky, H. M., and Childs, B. (1963). Demonstration of two populations of cells in the human female heterozygous for glucose-6-phosphate dehydrogenase variants. Proc. nat. Acad. Sci. (Wash.), 50, 481 .

Dern, R. J., Beutler, E., and Alving, A. S. (1954). The hemolytic effect of primaquine. II. The natural course of the hemolytic anemia and the mechanism of its self-limited character. $\mathcal{F}$. Lab. clin. Med., 44, I 7 I.

Frischer, H., Bowman, J., and Carson, P. (1964). Microscopic studies of G-6-PD deficient and HbM erythrocytes. Clin. Res., $12,86$.

Gorman, J. G., Dire, J., Treacy, A. M., and Cahan, A. (1963). The application of $-\mathbf{X g}^{\mathrm{a}}$ antiserum to the question of red cell mosaicism in female heterozygotes. ibid., 6r, 642 .

Gross, R. T., Hurwitz, R. E., and Marks, P. A. (1958). An hereditary enzymatic defect in erythrocyte metabolism: glucose-6-phosphate dehydrogenase deficiency. $\mathcal{f}$. clin. Invest., 37, 1 I 76.

Grumbach, M. M., Marks, P. A., and Morishima, A. (1962). Erythrocyte glucose-6-phosphate dehydrogenase activity and $\mathrm{X}$-chromosome polysomy. Lancet, $\mathbf{1}, 1330$.

Harris, H., Hopkinson, D. A., Spencer, N., Court Brown, W. M. and Mantle, D. (1963). Red cell glucose-6-phosphate dehydro- genase activity in individuals with abnormal numbers of $\mathrm{X}$ chromosomes. Ann. hum. Genet., 27, 59.

Kellermeyer, R. W., Tarlov, A. R., Schrier, S. L., Carson, P.尽., and Alving, A. S. (I96r). The hemolytic effect of primaquine. XIII. Gradient susceptibility to hemolysis of primaquinesensitive erythrocytes. f. Lab. clin. Med., 58, 225.

Kirkman, H. N. (1962). Electrophoretic differences of human erythrocytic glucose-6-phosphate dehydrogenase. Amer. F. $\overline{\bar{D}_{i}}$ s. Child., 104, 566.

-, Schettini, F., and Pickard, B. M. (1964). Mediterranean variant of glucose-6-phosphate dehydrogenase. F. Lab. Ein. Med., 63, 726 .

Larizza, P., Brunetti, P., Grignani, F., and Ventura, S. (I9:్త8). L'individualità bio-enzimatica dell'eritrocito "fabico". Haematologica, 43, 205.

Lyon, M. F. (1962). Sex chromatin and gene action in the mainmalian X-chromosome. Amer. F. hum. Genet., 14, 135

Oski, F. A., Shahidi, N. T., and Diamond, L. K. (I963). E⿺辶tythrocyte acid phosphomonoesterase and glucose-6-phosp然te dehydrogenase deficiency in Caucasians. Science, 139, 409.

Panizon, F., and Zacchello, F. (1965). The mechanism of haemolissis in favism: some analogy in the activity of primaquine and fava juice. Acta haemat. (Basel), 33, 129.

Papayannopoulou, Th., and Stamatoyannopoulos, G. (19 Pseudo-mosaicism in males with mild glucose-6-phosplate dehydrogenase deficiency. Lancet, $2,1215$.

Porter, I. H., Boyer, S. H., Watson-Williams, E. J., Adam, A. Szeinberg, A., and Siniscalco, M. (1964). Variation of glucosephosphate dehydrogenase in different populations. ibid., 1 , \$5

Russell, L. B. (1963). Mammalian X-chromosome action: inactivation limited in spread and in region of origin. Science, 140, ज्ञ6.

Sansone, G., Rasore-Quartino, A., and Veneziano, G. (1963). Dimostrazione su strisci di sangue di una doppia popolaziome eritrocitaria nelle donne eterozigoti per la deficienza in glucosło6-deidrogenasi. Pathologica, 55, 371.

Sartori, E., and Panizon, F. (1957). Nuove prospettive nello stufio del favismo. Studi sassaresi, XXXV, 363.

Siniscalco, M., Motulsky, A. G., Latte, B., and Bernini, L. (I 9 (6. Indagini genetiche sulla predisposizione al favismo. II. Fat familiari. Associazione genetica per il daltonismo. Accademia Lincei, Rend. Sc. Fis. Mat. e Nat., 28, 903.

Stamatoyannopoulos, G., Panayotopoulos, A., and Papayannopoufou, Th. (1964). Mild glucose-6-phosphate dehydrogenase deficiefscy in Greek males. Lancet, 2, 932.

Tarlov, A. R., Brewer, G. J., Carson, P. E., and Alving, A (1962). Primaquine sensitivity. Arch. intern. Med., 109, 20\% - , and Kellermeyer, R. W. (196I). The hemolytic effect of prifiaquine. XI. Decreased catalase activity in primaquine-sensitive erythrocytes. F. Lab. clin. Med., 58, 204.

Tönz, O., and Rossi, E. (1964). Morphological demonstration of two red cell populations in human females heterozygous for glucose-6-phosphate dehydrogenase deficiency. Nature (Lond.), 202, 606.

Zacchello, F. (1963). Ricerche in vitro sull'azione eritrolesiva dolla vitamina $\mathrm{K}_{3}$. Acta paediat. lat. (Reggio Emilia), 16, $58 \mathrm{I}$. 